\title{
Optimalisasi Jumlah Kebutuhan Tenaga Kerja pada Stasiun Kerja Hoisting Crane Menggunakan Metode Work Sampling (Studi Kasus: PT. X)
}

\author{
Muhammad Isnaini Hadiyul Umam ${ }^{1}$, Nofirza ${ }^{2}$, Muhammad Rizki ${ }^{3}$, Fitriani Surayya Lubis ${ }^{4}$ \\ 1,2,3,4 Jurusan Teknik Industri, Fakultas Sains dan Teknologi, UIN Sultan Syarif Kasim Riau \\ Jl. HR. Soebrantas No. 155 Simpang Baru, Panam, Pekanbaru, 28293 \\ Email: muhammad.isnaini@uin-suska.ac.id
}

\begin{abstract}
ABSTRAK
Manusia Menjadi salah satu faktor utama dalam menjamin kelancaran proses produksi pada suatu perusahaan atau industri. Ketersediaan tenaga kerja dengan tingkat keterampilan yang memadai dalam jumlah yang tepat merupakan salah satu kunci penting keberhasilan dalam mencapai pemenuhan permintaan. Tujuan dari penelitian ini adalah untuk mengetahui persen produktif rata-rata operator sehingga dapat ditentukan waktu standar yang diperlukan operator dalam melakukan tugasnya sehingga dapat ditentukan jumlah optimal kebutuhan tenaga kerja. Metode yang digunakan dalam penelitian ini adalah Metode Work Sampling. Metode ini adalah suatu teknik kerja untuk menentukan sejumlah pengamatan terhadap aktivitas kerja dari mesin, proses dan pekerja atau operator. Fokus penelitian ini dilakukan pada stasiun kerja Hoisting Crane karena pada stasiun ini terlihat para pekerja sering mengalami waktu menganggur. Berdasarkan hasil pengolahan data yang telah dilakukan, didapat bahwa persen produktif rata-rata pada masing-masing operator sebesar $92,37 \%$. Waktu standar yang dibutuhkan untuk sekali menuangkan lori ke mesin Hooper Theresser berjumlah 5,27 menit/lori, dan jumlah kebutuhan tenaga kerja yang sebenarnya dibutuhkan pada stasiun Hoisting Crane tersebut adalah sebanyak 4 orang dengan rincian 2 orang sebagai operator mesin crane, 1 orang sebagai pengarah lori dari stasiun rebusan menuju lintasan Crane dan 1 orang sebagai pengarah lori yang telah kosong kembali menuju jalur kepulangan ..
\end{abstract}

Kata Kunci: Man Power Planning, Work Sampling, Waktu Standar

\section{Pendahuluan}

Dewasa ini persaingan dalam dunia industri manufaktur semakin meningkat, baik dari segi jumlah maupun segi kualitas. Kelapa sawit merupakan salah satu komoditas andalan subsektor perkebunan yang menarik perhatian serius pemerintah, pihak investor serta petani terutama sejak tahun 1990-an.

Manusia menjadi salah satu faktor utama dalam menjamin kelancaran proses produksi pada suatu perusahaan atau industri. Ketersediaan tenaga kerja dengan tingkat keterampilan yang memadai dalam jumlah yang tepat merupakan salah satu kunci penting keberhasilan dalam mencapai pemenuhan permintaan. Dengan sumber daya manusia yang baik yang dimiliki oleh perusahaan tersebut akan berdampak pada lebih baiknya kualitas produksi yang dihasilkan. Olehkarena itu perusahaan harus memikirkan bagaimana cara untuk terus meningkatkan efektifitas dan efisiensi pekerjanya dalam bekerja. Dengan demikian, analisis beban kerja, julah tenaga kerja, studi gerak dan waktu memainkan peranan yang sangat penting.

Salah satu cara untuk meningkatkan produktifitas tenaga kerja adalah dengan menggunakan metode pengukuran kerja. Metode pengukuran kerja ini sangat baik digunakan dan diaplikasikan untuk menentukan waktu standar dan persentase waktu delay dari proses pembuatan suatu produk. Pengukuran waktu kerja berfungsi untuk menentukan lama kerja yang dibutuhkan seorang operator dalam menyeledaikan suatu pekerjaan yang spesifik pada tingkat kecepatan kerja yang normal dalam lingkunga kerja yang terbaik pada saat itu.

Pengukuran kerja ini dilakukan pada stasiun kerja Hoisting Crane di Pabrik Kelapa Sawit PT. X. Hal ini didasari karena pada stasiun kerja tersebut sering terlihat pekerja yang sering mengalami waktu menganggur. Untuk itu perlu ukur persen produktif dari pekerja, waktu standar, dan jumlah tenaga kerja yang optimal pada stasiun tersebut.

Menurut wignjosoebroto (1995) pengukuran waktu kerja terbagi menjadi 2 yaitu, pengukuran waktu kerja dengan metode pengukuran langsung dan pengukuran waktu kerja tidak langsung. Pengukuran kerja secara langsung adalah pengukuran kerja yang pengukurannya dilaksanakan secara langsung ditempat dimana pekerjaan yang diukur dijalankan. Dua cara yang terdapat didalamnya adalah dengan stop watch time study dan work sampling. Sedangkan pengukuran kerja secara tidak langsung merupakan pengukuran kerja yang malakukan perhitungan waktu kerja berdasarkan tabeltabel waktu yang tersedia. 


\section{Tinjauan Pustaka}

\section{Pengukuran Waktu Kerja}

Penelitian kerja dan analisa metode kerja pada dasarnya akan memusatkan perhatiannya pada bagaimana suatu macam pekerjaan akan diselesaikan. Dengan mengaplikasina prinsip dan teknik pengaturan cara kerja yang optimal dalam sistem kerja tersebut, maka akan diperoleh alternatif metoda pelaksanaan kerja yang dianggap memberikan hasil yang paling efektif dan efisien. Suatu pekerjaan akan dikatakan diselesaikan secara efisien apabila waktu penyelesaiannya berlangsung paling singkat.

\section{Aplikasi Work Sampling Menghitung Allowance}

Pada dasarnya setiap pekerjaan haruslah diberikan kelonggaran waktu untuk keperluan yang bersifat kebutuhan pribadi. Sutalaksana (1997) menyatakan bahwa ada dua hal yang perlu diperhatikan untuk memberikan allowance yaitu sifat dari kegiatan dan kewajaran.

\section{Aplikasi Work Sampling untuk Waktu Tunggu}

Dalam metoda work sampling, allowance merupakan suatu yang harus ditetapkan terlebih dahulu adalah membakukan metode kerja yang digunakan. Dengan mengetahui waktu-waktu menganggur maka tujuan utama dari aktivitas ini adalah berusaha menekan aktivitas-aktivitas yang diklasifikasikan sebagai kegiatan 'Non-produktif' sampai persentase yang terkecil. Hal ini bisa dilaksanakan dengan memperbaiki metode kerj, alokasi pembebanan mesin atau manusia secara tepat, dan lain-lain (Wignjosoebroto, 1995).

\section{Aplikasi Work Sampling menghitung Waktu Standar}

Seperti halnya dalam stopwatch time study, maka disini juga harus diestimasikan terlebih dahulu rating factor dari tenaga kerja yang diukur dan waktu kelonggaran yang ada. Sehingga waktu baku penyelesaian suatu produk dapat dihitung dengan :

Waktu Baku $=\frac{\text { TT } x \text { WT } x \text { RF }}{\sum \mathrm{Yi}} \times \frac{100 \%}{100 \%-\mathrm{All}}$

Dimana :

TT $=$ Total Time

WT $=$ Working Time

$\mathrm{RF} \quad=$ Rating Factor

$\sum \mathrm{Yi}=$ Total volume dilakukan operator

All = Allowance

\section{Perhitungan Jumlah Tenaga Kerja Berdasarkan Waktu Standar}

Waktu Standar sangat diperlukan terutama untuk man power planning. Waktu baku merupakan waktu yang diperlukan seorang pekerja untuk menyelesaikan pekerjaannya. Setelah waktu baku diketahui makan akan dilanjutkan dengan perhitungan jam kerja produktif dan waktu total pengerjaan produk. Untuk menentukan kebutuhan jumlah tenaga kerja standar dapat dilakukan dengan menganalisa beban kerjanya (Wignjosoebroto, 1995).

Beban Kerja $=\frac{\text { Volume Pekerjaan }}{\text { Waktu Normal } \times \frac{100 \%}{100 \%-\% \text { Allowance }}} \times 1$

Untuk menentukan jumlah pekerja-mesin yang diperlukan untuk aktivitas operasi maka digunakan rumus berikut :

$\mathrm{N}=\frac{\mathrm{T}}{60} \times \frac{\mathrm{P}}{\mathrm{D} \times \mathrm{E}}$

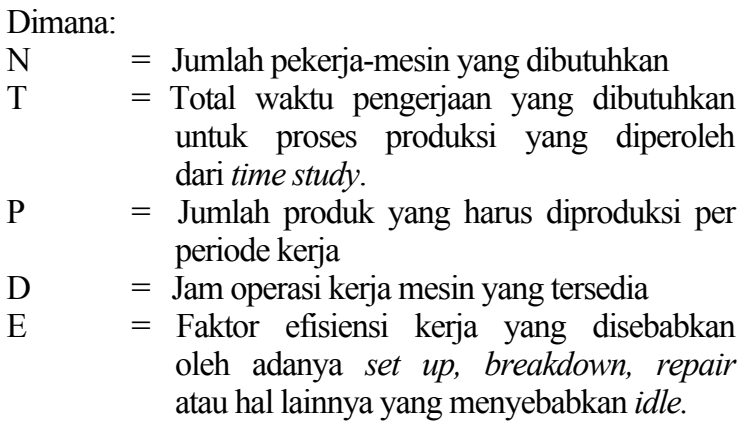

\section{Metode Penelitian}

Pada Tahapan ini akan dijabarkan langkahlangkah yang dilakukan untuk menyelesaikan permasalah jumlah kebutuhan operator yang optimal. Berdasarkan sifatnya penelitian ini merupakan penelitian deskriptif survei dan analisa kuantitatif, tujuannya adalah untuk menggambarkan keadaan secara objektif yang digunakan untuk memecahkan permasalahan yang sedang dihadapi. Objek yang diamati dapat dianggap mewakili dari populasinya, sehingga hasil dari penelitian ini dapat digeneralisasikan sebagai hasil dari populasi.

Metode pengumpulan data dilakukan secara pengamatan langsung (observasi), wawancara dan studi pustaka. Adapun data-data yang dikumpulkan adalah sebagai berikut:

1. Penetapan jumlah pengamatan

2. Pengamatan woek sampling

3. Pencatatan jumlah produk output

4. Penentuan rating factor

5. Perhitungan produktifitas operator

6. Uji keseragaman data

7. Uji kecukupan dataccc

8. Perhitungan derajat ketelitian

9. Perhitungan waktu baku

10. Perhitungan jumlah tenaga kerja 


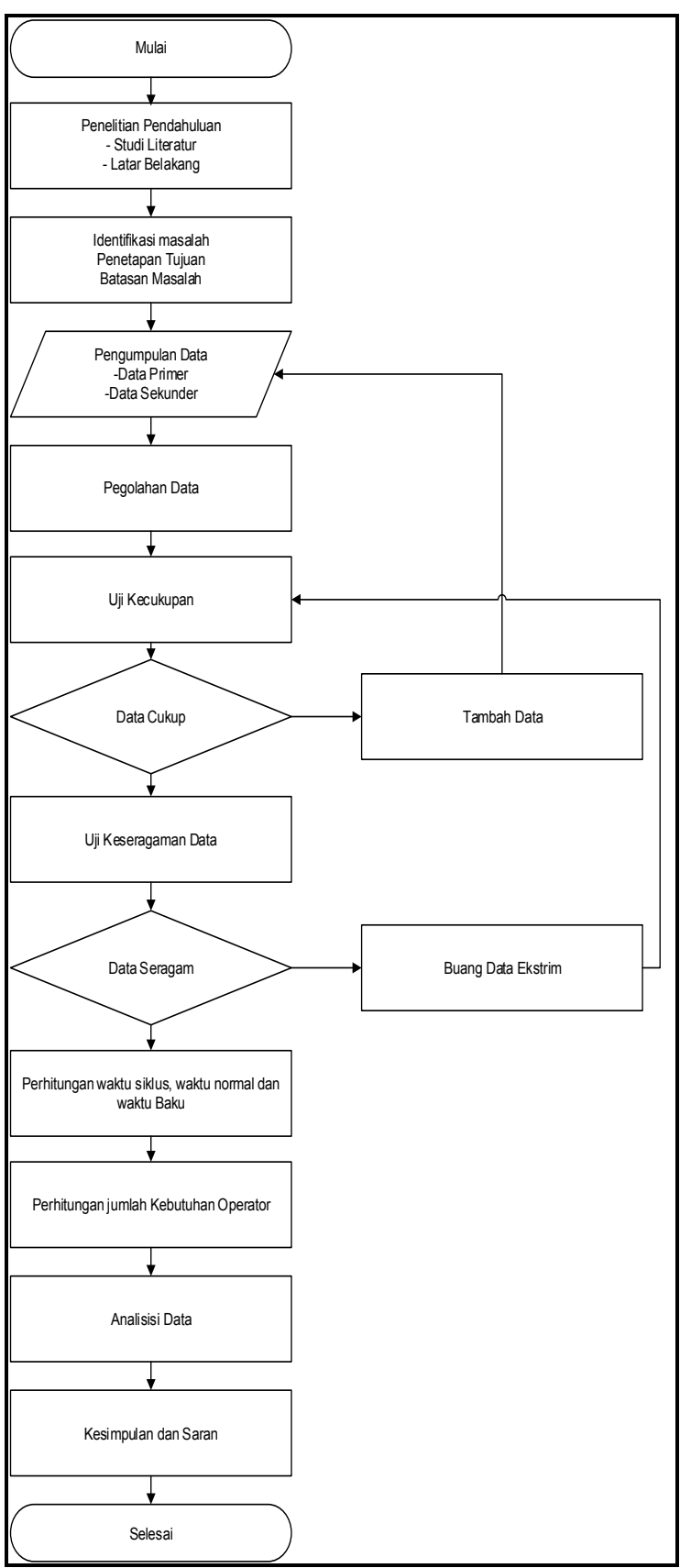

Gambar 1. Flowchart penelitian

\section{Hasil dan Pembahasan}

Penentuan jadwal pengamatan bertujuan untuk menetapkan waktu pengamatan pada suatau waktu mengenai kegiatan apa saja yang dilakukan operator pada selang waktu tersebut. Pada penelitian ini pengamatan dilakukan mulai dari pukul 07.00 - 19.00 WIB. Dengan selang interval waktu sebesar 10 menit sehingga didapat 72 bilangan acak yang harus dibangkitkan untuk melihat kapan saja harus melakukan pengamatan.

Pengamatan dilakuakn pada stasiun kerja Hoisting Crane dengan mengamati 3 orang operator. Pengamatan dilakuakan untuk melihat kegiatan-kegiatan yang termasuk produktif dan yang tidak produktif. Aktivitas produktif terkait dengan beban kerja dan tanggung jawab kerja, sedangkan aktivitas non-produktif yaitu segala aktivitas yang tidak terhitung beban kerja atau tanggung jawab yang diberikan kepada mereka.

Setelah didapat rating factor dan allowance yang diberikan pada masing-masing operator, dilakukan perhitungan persen produktif untuk masing-masing operator dengan rekapitulasi berikut :

Tabel 1. Rekapitulasi persen produktif operator

\begin{tabular}{cc}
\hline Operator & Produktivitas \\
\hline 1 & $93,7 \%$ \\
2 & $90,9 \%$ \\
3 & $92,5 \%$ \\
\hline
\end{tabular}

Setelah mendapat pengukuran persentase tingkat produktivitas kerja, maka pengolahan data dilanjutkan pada uji tingkat keseragaman data dan uji kecukupan data. Data diolah dengan tingkat kepercayaan sebesar 95\% dan tingkat ketelitian 5\%. Dari hasil pengolahan data, tidak ditemukan adanya data yang out of control dan data dinnyatakan telah mencukupi syarat sehingga dapat dilanjutkan untuk menghitung waktu standar masing-masing pekerja sebagai acuan untuk menentukan jumlah tenaga kerja yang dibutuhkan.

\section{Perhitungan Waktu Standar}

Tujuan dari perhitungan waktu standar ini adalah untuk mengetahui seberapa besar waktu yang diperlukan operator untuk menyelesaikan sebuah pekerjaan yang ditugakan pada mereka. Berdasarkan rating factor dan allowance yang telah didapat pada masing-masing operator maka waktu standar untuk masing-masing operator dapat dihitung sebagai berikut :

1. Operator 1

a. Jumlah pengamatan $=207$

Jumlah produktif $\quad=194$

Presentase produktif $\quad=\frac{197}{207} \times 100=93,7 \%$

b. Jumlah menit pengalaman $=1440$ Menit

Jumlah menit produktif $\quad=93,7 \% \times 1440$

$=1349,28$

c. Jumlah lori $\quad=360$ Lori

Yang dituangkan

d. Waktu yang diperlukan $=\frac{1349,28}{360}=3,748$ Setiap lori menit/ lori

e. Waktu Normal

$=$ Siklus $\times$ Penyesuaian $=3,748 \times(1+0,14)$

$=4,27$ Menit 
f. Waktu standar

$$
\begin{aligned}
= & \text { Waktu normal }+ \\
& \text { Allowance } \\
= & 4,27+0,24(4,27) \\
= & 5,3 \text { menit }
\end{aligned}
$$

2. Operator 2

a. Jumlah pengamatan $=231$

Jumlah produktif $\quad=210$

Presentase produktif $\quad=\frac{210}{231} \times 100=90,9 \%$

b. Jumlah menit pengalaman $=1440$ Menit

Jumlah menit produktif $\quad=90,9 \% \times 1440$

$=1308,96$

c. Jumlah lori $\quad=360$ Lori

Yang dituangkan

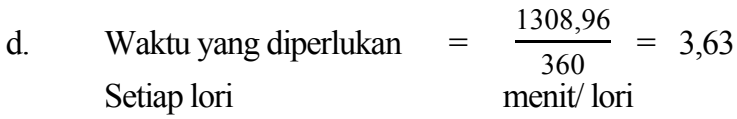

e. Waktu Normal = Siklus $\times$ Penyesuaian

$=3,63 \times(1+0,1)$

$=4$ Menit

f. Waktu standar

$=$ Waktu normal +

Allowance

$=4+0,305(4)$

$=5,22$ menit

3. Operator 3

a. Jumlah pengamatan $=220$

Jumlah produktif $\quad=204$

Presentase produktif $\quad=\frac{220}{204} \times 100=92,5 \%$

b. Jumlah menit pengalaman $=1440$ Menit

Jumlah menit produktif $\quad=92,5 \% \times 1440$

$=1332$

c. Jumlah lori $\quad=360$ Lori

Yang dituangkan

d. Waktu yang diperlukan $=\frac{1332}{360}=3,7$
$\begin{aligned} & \text { Setiap lori } \\ & \text { menit/ lori }\end{aligned}$

e. Waktu Normal = Siklus $\times$ Penyesuaian

$=3,7 \times(1+0,1)$

$=4,07$ Menit f. Waktu standar

$$
\begin{aligned}
= & \text { Waktu normal }+ \\
& \text { Allowance } \\
= & 4,07+0,305(4) \\
= & 5,3 \text { menit }
\end{aligned}
$$

Perbedaan yang terjadi pada waktu standar masing-masing pekerja disebabkan oleh perbedaan rating factor dan kelonggaran yang diberikan pada masingmasing operator tersebut. Sedangkan untuk Waktu Standar pada stasiun kerja Hoisting Crane adalah rata-rata dari ketiga waktu standar operator-operator tersebut.

$\frac{\mathrm{Ws} 1+\mathrm{Ws} 2+\mathrm{Ws} 3}{3}$

$=\frac{5,3+5,22+5,3}{3}=5,27$ menit setiap lori

\section{Analisis Beban Kerja}

Berikutnya adalah menentukan berapa jumlah optimum dari tenaga kerja yang dibutuhkan pada stasiun kerja tersebut. Dapat dihitung dengan menganalisi beban kerja pada masing-masing operator.

1. Operator 1

$$
\begin{aligned}
& =\frac{53}{60} \times \frac{131.400}{8760 \times 0,8} \\
& =1,65 \text { Orang } \approx 2 \text { Orang }
\end{aligned}
$$

2. Operator 2

$$
\begin{aligned}
& =\frac{3,636 \text { Menit/lori }}{5,22 \text { Menit/lori }} \times 1 \\
& =0,7 \text { Orang } \approx 2 \text { Orang }
\end{aligned}
$$

3. Operator 3

$$
\begin{aligned}
& =\frac{3,7 \text { Menit/lori }}{5,3 \text { Menit/lori }} \times 1 \\
& =0,7 \text { Orang } \approx 2 \text { Orang }
\end{aligned}
$$

\section{Kesimpulan}

Berdasarkan hasil pengolahan dan analisa data yang telah dilakukan maka dapat disimpulkan persen produktif rata-rata seluruh operator adalah sebesar 92,37\%. Waktu standar yang dibutuhkan untuk sekali menuangkan lori ke masin Hooper Thresser sebesar 5,27 menit/lori. Sedangkan untuk jumlah kebutuhan tenaga kerja pada stasiun tersebut yang pada awalnya berjumlah 6 orang berkurang menjadi 4 orang saja dengan rincian 2 orang yang berkerja sebagai operator mesin crane, 1 orang sebagai pengarah lori menuju lintasan crane, dan 1 orang lagi bertugas mengarahkan lori yang telah kosong menuju jalur kepulangan lori. 


\section{Daftar Pustaka}

[1] Anna, I. D. 2010. Penentuan jumlah Operator optimal dengan menggunakan wark sampling, Universitas Trunojoyo.

[2] Barnes, R. 1980. Motion and Time study: Design and Measurement of work, Newyork: Jhon Wiley \& Sons.

[3] Hartono, 2008. Perencanaan Kebutuhan tenaga kerja pada perudahaan jasa penyeberangan Ujung-Kamal. Malang : Jurnal Teknik Industri, Vol.9, No.2 Agustus 2008: 95-101.

[4] Sutalaksana, I. 1995. Teknik Tata Cara Kerja, Bandung: TI ITB.

[5] Wignjosoebroto, Sritomo. 1995. Ergonomi, Studi Gerak dan Waktu. Surabaya: Prima Printing. 